\title{
Acta
Biochimica
Polonica
}

Vol. 51 No. 3/2004

$673-681$

QUARTERLY

\section{Restriction analysis of genetic variability of Polish isolates of Tomato black ring virus}

\author{
Magdalena Jończyk ${ }^{凶}$, Natasza Borodynko and Henryk Pospieszny \\ Department of Virology and Bacteriology, Institute of Plant Protection, Poznań, Poland
}

Received: 04 August, 2003; revised: 15 April, 2004; accepted: 23 April, 2004

Key words: Tomato black ring virus, phylogeny, restriction analysis, genetic variability

\begin{abstract}
Several different isolates of Tomato black ring virus (TBRV) have been collected in Poland from cucumber, tomato, potato and black locust plants. Biological tests showed some differences in the range of infected plants and the type of symptoms, which was the basis for selection of seven the most biologically different TBRV isolates. According to the sequence of TBRV-MJ, several primer pairs were designed and almost the entire sequence of both genomic RNAs was amplified. The RT-PCR products derived from all tested TBRV isolates were digested by restriction enzymes. On the basis of the restriction patterns, the variable and the conserved regions of the TBRV genome were defined and the relationships between the Polish TBRV isolates established.
\end{abstract}

Tomato black ring virus (TBRV) belongs to the Nepovirus genus of positive, single stranded RNA plant viruses. Its genome is divided into two RNAs: RNA1 containing the genes important for virus replication and polyprotein processing and RNA2 containing genes responsible for the synthesis of viral capsid protein and the movement of the virus in plants (Demangeat et al., 1990; 1991; Grief et al., 1988; Mayer et al., 1986; Le Gall et al., 1995a). Earlier, some Polish TBRV isolates were found in potato (Chrzanowska \& Śniegowski, 1965), tomato (TwardowiczJakusz, 1969), celery (Twardowicz-Jakusz, 1976), carrot (Twardowicz-Jakusz et al., 1977a), horseradish (Twardowicz-Jakusz et al., 1977b), privet (Błaszczak \& Pospieszny 1987), forsythia (Kamińska \& Sobiło, 1983),

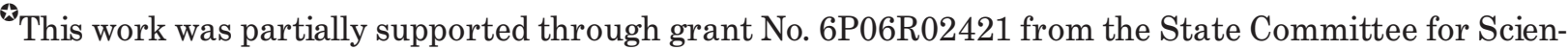
tific Research (KBN, Poland).

Accession numbers for TBRV-MJ full-length sequence of RNA1: NC 004439 and RNA2: NC 004440.

${ }^{\otimes}$ Corresponding author: Magdalena Jończyk; Department of Virology and Bacteriology, Institute of Plant Protection, Miczurina 20, 60-318 Poznań, Poland; phone: (48 61) 864 9092, fax: (48 61) 8676301 ; m.palczewska@ior.poznan.pl
}

Abbreviations: GFLV, Grapevine fanleaf virus; nt, nucleotides; TBRV, Tomato black ring virus. 
gladiolus and flox (Kamińska \& Woś, 1978). Those isolates, except the one from potato, are no longer available. Recently, we have collected some new TBRV isolates in Poland. Most of them were isolated from old black locust plants (Pospieszny \& Borodynko, 1999; Borodynko et al., 2001), one isolate from tomato (Pospieszny \& Borodynko, 1999) and one from cucumber (Pospieszny et al., 2003). In contrast to their biological variability, all the Polish TBRV isolates tested appeared serologically similar to each other (Borodynko et al., 2001).

RNA viruses have a high capability of rapid genetic changes due to the frequent point mutations and genome rearrangement that are held to be the main mechanism in the evolution of RNA viruses (Drake 1993; Dolja \& Carrington, 1992; Domingo \& Holland, 1997, Roossinck, 1997). The majority of the point mutations in the viral genomes are neutral for the encoded amino-acid sequence but probably they might influence the RNA structure and adaptation to the host translation machinery (Huynen et al., 1996; Leisner \& Neher, 2002; Roossinck, 2002). RNA recombination might be responsible for the viral sequence variability, repair of some defective RNA molecules as well as production of shortened form of viral RNA, called defective interfering RNAs (Bruyere et al., 2000; Kim \& Kao 2001; Nagy \& Bujarski, 1998). These truncated RNA molecules might interfere with virus replication and change the symptoms severity in infected plants (Graves et al., 1996; Hernandez et al., 1996; Cheng et al., 2002; Szittya et al., 2002).

The variability of RNA viruses is also connected with specified parts of their genomes. Generally, the most conservative is the region encoding polymerase (Dolja \& Carrington, 1992; Zaccomer et al., 1995; Koonin 1991). The coat protein gene is usually variable and virus species specific, and due to its responsibility for the specification of the viral serotype and species it is frequently used in phylogenic analyses (Dolja \& Carrington,
1992; Zaccomer et al., 1995; Petrzik \& Lenz, 2002; Canizares et al., 2001). Many other viral proteins, especially those of unknown function, are only rarely used in viral phylogeny due to their often one-species-specific nature and a lack of counterparts in other viral species (Zaccomer et al., 1995).

The knowledge of virus population diversity and the distribution of the variable and conserved regions within the viral genomes may be useful in sequence-specific detection of viruses, the prediction of occurrence of resistance-breaking viral phenotypes as well as in developing new methods of plant protection.

In this paper we report the genetic variability of Polish TBRV isolates on the basis of restriction analysis of almost full-length cDNA derived from both viral RNAs.

\section{MATERIALS AND METHODS}

TBRV isolates. The TBRV isolates studied originated from the following plant species: cucumber (TBRV-Cuc), tomato (TBRV-Tom), black locust (TBRV-L10, TBRV-MJ, TBRV-N1, TBRV-Pn) and potato (TBRV-Pot). TBRV-Pot was kindly supplied by Prof. M. Chrzanowska (IHAR, Radzików, Poland), the other isolates were from our collection. The biological properties of the TBRV isolates were studied by mechanical inoculation of various plant species. The host range and symptoms allowed selection of the isolates displaying the most distinct properties. All the isolates were maintained and propagated in Chenopodium quinoa in the greenhouse.

Purification of viral RNA. The TBRV isolates were propagated in C. quinoa and purified as described before (Pospieszny \& Borodynko, 1999). The purified viral particles were digested with proteinase $\mathrm{K}$ and RNA was isolated according to the phenol/chloroform protocol (Sambrook et al., 1989), precipitated with $96 \%$ ethanol and pellet was dissolved in RNase-free water, then $2 \mu \mathrm{l}$ of RNA solution were mixed with $10 \mu \mathrm{l}$ of Formazol 
(MRC) and separated on 1\% agarose non-denaturing gel.

RT-PCR amplification of RNA1 and $\boldsymbol{R N A 2}$. The purified viral RNA was reverse transcribed using SuperScript II reverse transcriptase (Invitrogen) according to manufacturer's instructions. The primer used for the first strand synthesis was oligo $\mathrm{d}(\mathrm{T})_{22}$ and the full-length cDNAs obtained were amplified using four pairs of primers designed according to the TBRV-MJ sequence (Accession number: NC 004439 and NC 004440 for RNA1 and RNA2, respectively). The first primer pair (P-128 and 1MP2) amplified the $5^{\prime}$ part of RNA1 about 2900 nt in length, the second one (1MP3 and 3ter) about $3600 \mathrm{nt}$ from the $3^{\prime}$ part of RNA1, the third (P-128 and 2MP2) the $5^{\prime}$ part of RNA2 of about $3200 \mathrm{nt}$ and the last pair (2MP5 and 3ter) amplified the 3 ' part of RNA2 about $2300 \mathrm{nt}$ in length (Table 1). The obtained PCR products covered the entire coding sequence of RNA2 and almost entire sequence of RNA1, excluding about $800 \mathrm{nt}$ from the region coding for NTP-binding protein. The amplification of cDNA obtained from seven Polish TBRV isolates was performed using ExpandLong PCR System (Roche) according to the manufacturer's instruction.

Restriction digestion of PCR derived products. The restriction enzymes were chosen on the basis of TBRV-MJ sequence using the MapDraw program from the DNA Star package (kindly made available by Institute of Biochemistry and Biophysics, Polish Acad- emy of Sciences, Warszawa, Poland). Each RT-PCR product was digested by two different enzymes in two distinct restriction experiments and the digestion products were resolved on 2.5\% NuSieve 3:1 agarose gel (BMA). The patterns obtained were analyzed in two aspects: firstly, a comparative analysis of conserved and variable regions was performed according to the bands of known size derived from TBRV-MJ and secondly, on the basis of the restriction fragments, 124 characters for phylogenetic analysis of the Polish TBRV isolates were obtained. The clustering and genetic distances assessment was performed using the program FreeTree (Pavlicek et al., 1999). The phylogeny tree was bootstraped 1000 times and constructed using the TreeView program (Page, 1996). The genomic mapping of the restriction bands obtained was established by comparison with TBRV-MJ patterns.

\section{RESULTS}

\section{Analysis of viral RNA}

Analysis of purified viral RNA showed two RNA bands of a size typical for TBRV. For the majority of the isolates some additional bands of small non-genomic RNA appeared (Fig. 1). The origin of these small RNAs is unclear. The RNAs expected for TBRV satellite are about 1350 nucleotides in length (Hemmer et al., 1993; Fritsch et al., 1984; 1993) and the

Table 1. The sequences of used primers

\begin{tabular}{l|l}
\hline Primer & Sequence \\
\hline P128 (+) & $\begin{array}{l}\text { caa atc ctg taa cca act ag } \\
\text { (t) } 18 \text { ttg ctt ttt gca gaa aac att tta tca } \\
\text { tat aca aa }\end{array}$ \\
3ter $(-)$ & tgg att ttc cgg gtc ata ga \\
1MP2 (-) & ttc tgg atg ggg att ctg g \\
1MP3 (+) & tg gat atg tca atg ggt tc \\
2MP2 (-) & tgg gat 2 get \\
2MP5 (+) & act tca ggg ctt tcc gct \\
\hline
\end{tabular}


observed bands are mostly smaller. We also observed that those small, non-genomic RNAs could emerge during prolonged propagation of the isolates originally devoid of them (not shown).

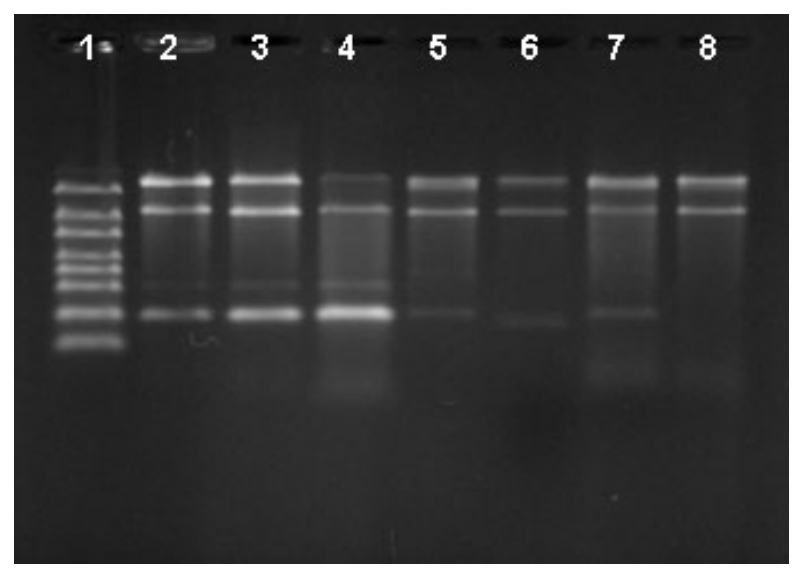

Figure 1. Electrophoretic patterns of RNAs of Polish TBRV isolates.

Lane 1, RNA ladder (6000, 4000, 3000, 2000, 1500, 1000, 500, $200 \mathrm{nt}$ ); lane 2, TBRV-L10; lane 3, TBRV-MJ; lane 4, TBRV-N1; lane 5, TBRV-Cuc; lane 6; TBRV-Tom; lane 7, TBRV-Pn; lane 8, TBRV-Pot.

\section{RT-PCR amplification of RNA1 and RNA2}

In RT-PCR amplification four products were obtained for each tested TBRV isolate. Two of them correspond to the RNA1 sequence and two others to RNA2. All the products obtained were of comparable size. The putative organization of the RT-PCR products is shown in Fig. 2. The displayed numbers of nucleotides corresponding to the cleavage sites for both TBRV-MJ polyproteins have been discussed elsewhere (Jończyk et al., 2004).

\section{Restriction digestion of PCR derived prod- ucts}

Restriction analyses of the RT-PCR products showed differences among the TBRV isolates. A higher diversity in the restriction patterns was observed for RNA1 and the restriction patterns were more diverse for the RT-PCR products corresponding to the genes in the 5 ' end proximity of both genomic RNAs. Figures $3 \mathrm{a}$ and $3 \mathrm{~b}$ show examples of the restriction patterns of the isolates in com-

RNA1
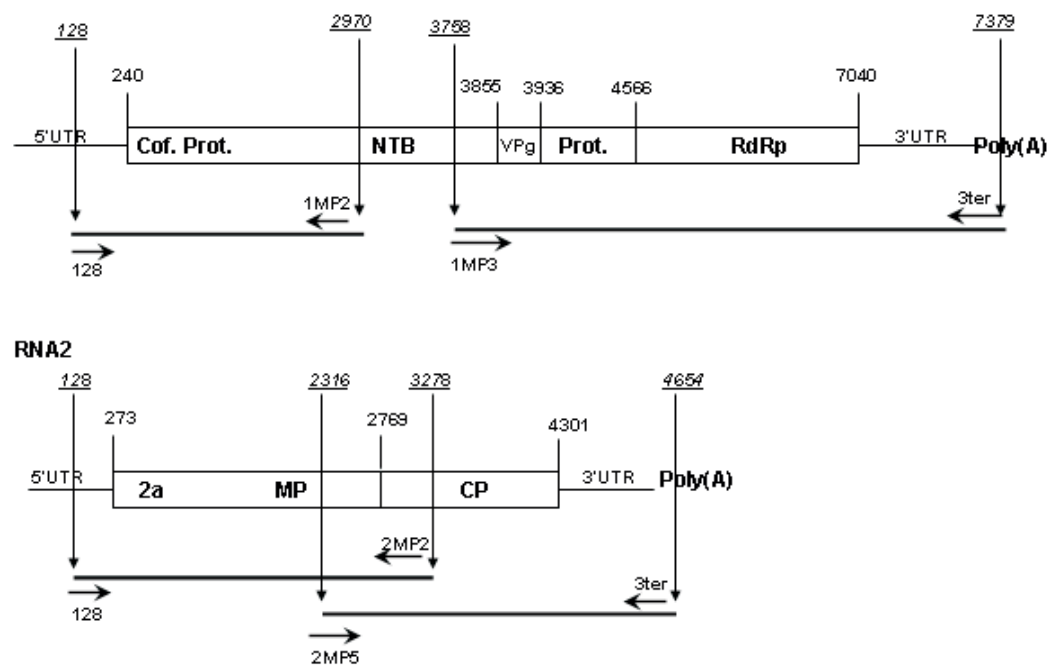

Figure 2. TBRV genome organization and location of primers and RT-PCR products.

RdRp, RNA-dependent RNA polymerase; Cof.Prot, protease cofactor; NTB, NTP-binding protein; Prot, protease; 2a, 2a protein; MP, movement protein; CP, coat protein. The numbers presented in regular numerals indicated the nucleotides corresponding to putative cleavage sites for TBRV polyproteins and the numbers in italics and underlined correspond to the sites of primer annealing. 


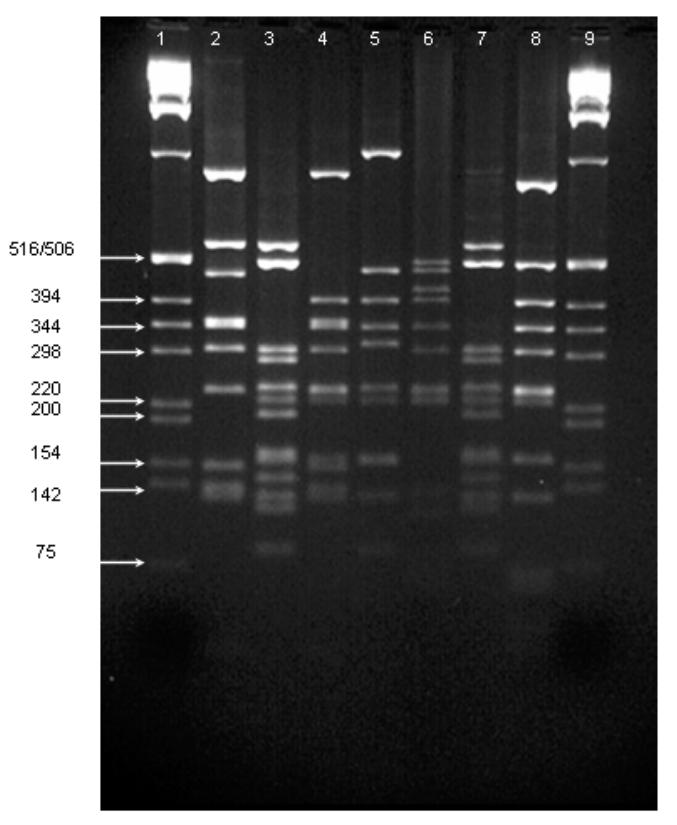

\begin{tabular}{|c|c|c|c|}
\hline \# & $\begin{array}{c}\text { Coor dinates acc ording to } \\
\text { nucleotides in PCR } \\
\text { product derved from } \\
\text { TERV-MJJ }\end{array}$ & $\begin{array}{c}\text { Length } \\
\text { (bp) }\end{array}$ & $\begin{array}{c}\text { Putative part of } \\
\text { TQRV-MJ } \\
\text { genome }\end{array}$ \\
\hline 1 & $2235-2792$ & 558 & RdRp \\
\hline 2 & $1731-2234$ & 504 & RdRp \\
\hline 3 & $669-1170$ & 502 & ProtRdRp \\
\hline 4 & $368-668$ & 301 & Prot \\
\hline 5 & $1171-1455$ & 285 & RdRp \\
\hline 6 & $3152-3392$ & 241 & RdRp/3'UTR \\
\hline 7 & $3393-3621$ & 228 & 3 UTR \\
\hline 8 & $152-356$ & 205 & VpG/Prot \\
\hline 9 & $1568-1730$ & 163 & RdRp \\
\hline 10 & $2915-3069$ & 155 & RdRp \\
\hline 11 & $13-151$ & 139 & NTBNpG \\
\hline 12 & $2793-2914$ & 122 & RdRp \\
\hline 13 & $1456-1567$ & 112 & RdRp \\
\hline 14 & $3070-3151$ & 82 & RdRp \\
\hline 15 & $1-12$ & 12 & NTB \\
\hline 16 & $357-367$ & 11 & Prot. \\
\hline
\end{tabular}

Figure 3a. RT-PCR products of the 3' part of RNA1 digested by Hinf.

Lane 1 and 9, $1 \mathrm{~Kb}$ DNA ladder (GibcoBRL); lane 2, TBRV-L10; lane 3, TBRV-MJ; lane 4, TBRV-N1; lane 5, TBRV-Cuc; lane 6, TBRV-Tom; lane 7, TBRV-Pn; lane 8, TBRV-Pot.

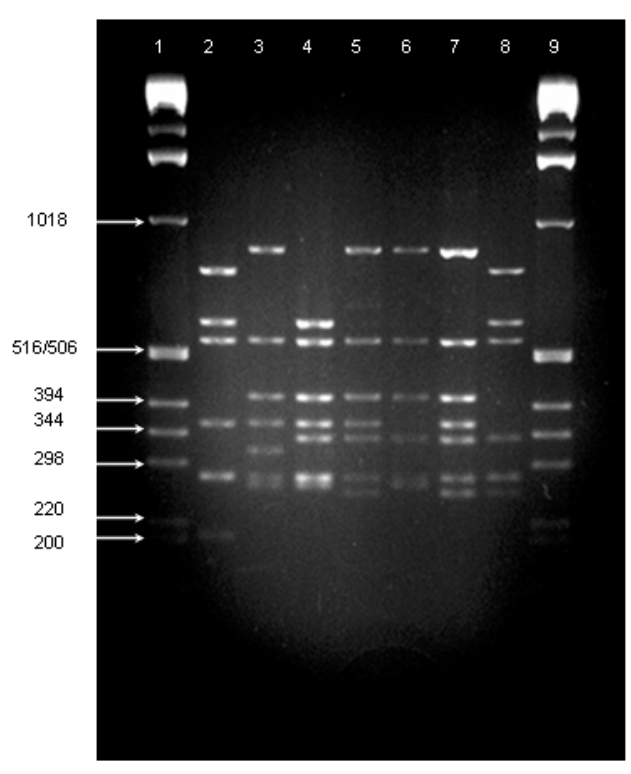

\begin{tabular}{|c|c|c|c|}
\hline$\#$ & $\begin{array}{c}\text { Coordinates according to } \\
\text { nucleotides in PCR product } \\
\text { derived from TBRV-MJ }\end{array}$ & $\begin{array}{c}\text { Length } \\
\text { (bp) }\end{array}$ & $\begin{array}{c}\text { Putative part of } \\
\text { TBRV-MJ genome }\end{array}$ \\
\hline 1 & $580-1450$ & 871 & 2a/MP \\
\hline 2 & $2625-3170$ & 546 & $\mathrm{CP}$ \\
\hline 3 & $1813-2223$ & 411 & $\mathrm{MP}$ \\
\hline 4 & $1451-1812$ & 362 & $\mathrm{MP}$ \\
\hline 5 & $1-314$ & 314 & 5 'UR/2a \\
\hline 6 & $2350-2624$ & 275 & $\mathrm{CP}$ \\
\hline 7 & $315-579$ & 265 & $2 \mathrm{a}$ \\
\hline 8 & $2224-2288$ & 65 & $\mathrm{CP}$ \\
\hline 9 & $2289-2349$ & 61 & $\mathrm{CP}$ \\
\hline
\end{tabular}

Figure 3b. RT-PCR products of the 5' part of RNA2 digested by Hinf.

For details see legends to Fig. 3a.

parison with those of TBRV-MJ for which the full-length sequence of both RNAs was already known.
The obtained restriction patterns allowed creation of a dendrogram of the relationship for the Polish TBRV isolates (Fig. 4). The re- 
sulting tree was not supported by high bootstrap values for the isolates from crops. Four TBRV isolates from black locust were clustered into two pairs: TBRV-Pn with TBRV-MJ and TBRV-N1 with TBRV-L10. The genetic distance (Nei and $\mathrm{Li}$ ) within a pair was much lower (e.g. 0.20879 between TBRV-MJ and TBRV-Pn) than between the pairs (e.g. 0.5713 between TBRV-N1 and TBRV-MJ). The iso-

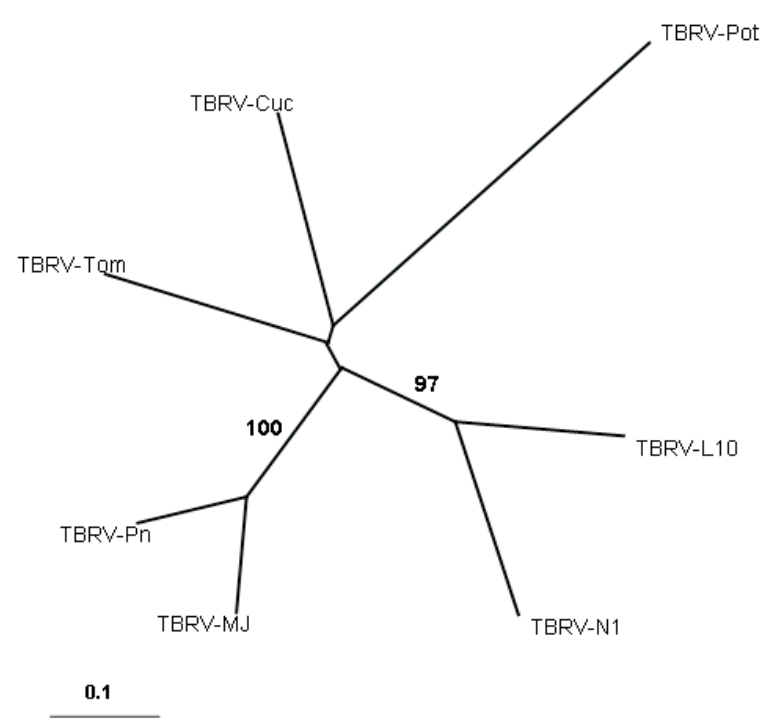

Figure 4. Dendrogram of the relationships between Polish TBRV isolates.

lates from crop plants were more similar to each other than to the isolates from black locust. The most different among the isolates originating from crops was TBRV-Pot.

\section{DISCUSSION}

The Polish TBRV population is an interesting example of RNA virus diversity in a few plant species. The presented restriction analysis gave an overall view into the genetic variability of the isolates and allowed prediction of distribution of mutations within the TBRV genome. The restriction tests performed create a basis for phylogenic analyses of the Polish TBRV isolates as well as permit a prediction of their likely evolution in Poland.
Contrary to our expectation, the restriction analyses showed diverse patterns for RNA1 and quite homogenous ones for RNA2. RNA1 encodes all the proteins thought to be highly conserved (e.g., RNA-dependent RNA polymerase or protease) and RNA2 encodes a capsid and a movement protein. While the movement protein is often considered conserved (Mushegian 1994; Melcher 2000), the coat protein usually varies within species (Steinkellner et al., 1992; Petrzik \& Lenz 2002; Canizares et al., 2001). In fact, all Polish TBRV isolates were serologically similar, if not identical, in the tests performed such as ELISA or double-diffusion test (Borodynko et al., 2001).

The sequences in the 5 ' end proximity of both RNAs, coding for a putative protease cofactor and 2a protein on RNA1 and RNA2, respectively, appeared to have more variable restriction patterns in comparison with the sequences in the 3 ' end proximity of the RNAs. The role of the former proteins in the TBRV life cycle is not clear. Protein 2a, similarly to 2a protein of Grapevine fanleaf virus (GFLV), might participate in replication of RNA2 (Gaire et al., 1999) and the putative protease cofactor might modulate the activity of viral protease especially for polyprotein 2 maturation (Hemmer et al., 1995). Unfortunately, the mechanisms of RNA2 replication and polyprotein 2 maturation are not completely understood for TBRV and it cannot be excluded that $2 \mathrm{a}$ protein and the putative protease cofactor have quite different functions in the TBRV life cycle.

Restriction analysis cannot provide information concerning amino-acid variability or their influence on the viral proteins' properties. However, it should be considered that even the silent mutations that do not influence the amino-acid sequence, can modulate RNA structure. Single nucleotide substitutions might also facilitate virus adaptation to the host translation machinery due to the correlation of the viral amino-acid codons with the ones used by the host plant (Roossinck 
2002; Leisner \& Neher, 2002). The tests performed allowed establishing the existence of a genetic diversity of the Polish TBRV isolates and indicated which part of their genomes probably gathered or/and maintained the diversity.

The phylogenic relationships between the Polish TBRV isolates were established on the basis of restriction fragment length polymorphism analysis. The resulting dendrogram clustered the isolates from black locust into two groups and such clustering was supported by high bootstrap values (Fig. 4). The situation was different for the isolates from crops because the very low bootstrap values prevented us from identification of the most likely relationships.

Most of the Polish TBRV isolates have some additional RNA particles associated and encapsidated with the viral RNAs. Their atypical size and also abundant amount suggested their defective rather than satellite nature. This suggestion was supported by the observation that the small RNAs originated during serial passages of a non-genomic-RNA-free isolate in C. quinoa (not shown). The isolates after passages usually displayed decreased severity.

The best method for estimation of real variation among viral genomes is sequencing. However, this is usually done for a short part of the coding sequence and is typically limited to one or sometimes two most typical viral proteins. The restriction tests performed enabled a preliminary characterization of the Polish TBRV population according to almost entire genomic sequence and indicated in which part of the genome the variability was localized.

The authors are grateful to Dr Andrzej Pałucha (Institute of Biochemistry and Biophysics, Polish Academy of Sciences, Warszawa, Poland) for his kind help in sequence analysis and for helpful discussion.

\section{R E F E R E N C E S}

Blaszczak W, Pospieszny H. (1987) Ligustrum vulgare - a natural host of the Tomato black ring virus. Prace naukowe IOR, Poznan.; 29: 126-36.

Borodynko N, Palczewska M, Pospieszny H. (2001) Serological variability of Polish isolates of Tomato black ring nepovirus (in Polish). Prog Plant Protection/Post Ochrony Roślin.; 41: 696-8.

Bruyere A, Wantroba M, Flasinski S, Dzianott A, Bujarski JJ. (2000) Frequent homologous recombination events between molecules of one RNA component in a multipartite RNA virus. $J$ Virol.; 74: 4214-9.

Canizares MC, Marcos JF, Pallas V. (2001) Molecular variability of twenty-one geographically distinct isolates of Carnation mottle virus (CarMV) and phylogenetic relationships within the Tombusviridae family. Arch Virol.; 146: 2039-51.

Chrzanowska M, Śniegowski C. (1965) Wirus pstrej plamistości łodygi, bukietowatości i mozaiki lucerny na ziemniakach oraz sposoby ich rozpoznawania. Biul Inst Hod Aklim Roślin.; 5/6: 77-85 (in Polish).

Cheng CP, Pogany J, Nagy PD. (2002) Mechanism of DI RNA formation in tombusviruses: Dissecting the requirement for primer extention by the tombusvirus RNA-dependent RNA polymerase in vitro. Virology.; 304: 460-73.

Demangeat G, Greif C, Hemmer O, Fritsch C. (1990) Analysis of the in vitro cleavage products of the tomato black ring virus RNA1 encoded $250 \mathrm{~K}$ polyprotein. $J$ Gen Virol.; 71: 1649-54.

Demangeat G, Hemmer O, Fritsch C, Le Gall O, Candresse T. (1991) In vitro processing of the RNA2 encoded polyprotein of two nepoviruses: tomato black ring virus and grapevine chrome mosaic virus. J Gen Virol.; 72: $247-52$.

Dolja VV, Carrington JC. (1992) Evolution of positive-strand RNA viruses. Semin Virol.; 3: $315-26$. 
Domingo E, Holland JJ. (1997) RNA virus mutations and fitness for survival. Annu Rev Microbiol.; 51: 151-78.

Drake JW. (1993) Rates of spontaneous mutation among RNA viruses. Proc Natl Acad Sci USA.; 90: 4171-5.

Fritsch C, Koenig I, Murant AF, Raschke JH, Mayo MA. (1984) Comparison among satellite RNA species from five isolates of Tomato black ring virus and one isolate of $\mathrm{My}$ robalan latent ringspot virus. $J$ Gen Virol.; 63: 289-94.

Fritsch C, Mayo M, Hemmer O. (1993) Properties of the satellite RNA of nepoviruses. Biochimie.; 75: 561-7.

Gaire F, Schmitt C, Stussi-Garaud C, Pinck L, Ritzenthaler C. (1999) Protein 2A of grapevine fanleaf nepovirus is implicated in RNA2 replication and colocalizes to the replication site. Virology.; 264: 25-36.

Graves MV, Pogany J, Romero J. (1996) Defective interfering RNAs and defective viruses associated with multipartite RNA viruses of plants. Semin Virol.; 7: 399-408.

Grief C, Hemmer O, Fritsh C. (1988) Nucleotide sequence of Tomato black ring virus RNA-1. $J$ Gen Virol.; 69: 1517-29.

Havelda Z, Szittya G, Burgyan J. (1998) Characterization of the molecular mechanism of defective interfering RNA-mediated symptoms attenuation in Tombusvirus-infected plants. $J$ Virol.; 72: 6251-6.

Hemmer O, Greif C, Dufourcq P, Reinbolt J, Fritsch C. (1995) Functional characterization of the proteolytic activity of the tomato black ring nepovirus RNA-1-encoded polyprotein. Virology.; 206: 362-71.

Hemmer O, Oncino C, Fritsch C. (1993) Efficient replication of the in vitro transcripts from cloned cDNA of tomato black ring virus satellite RNA requires the $48 \mathrm{~K}$ satellite RNA-encoded protein. Virology.; 194: 800-6.

Hernandez C, Carette JE, Brown DJF, Bol J. (1996) Serial passage of Tobacco rattle virus under different selection conditions results in deletion of structural and nonstructural genes in RNA2. $J$ Virol.; 70: 4933-40.
Holland J, Spindler K, Horodyski F, Grabau E, Nichol S, VandePol S. (1982) Rapid evolution of RNA genomes. Science.; 215: 1577-85.

Huynen MA, Stadler PF, Fontana W. (1996) Smoothness within ruggedness: the role of neutrality in adaptation. Proc Natl Acad Sci USA.; 93: 397-401.

Jończyk M, Le Gall O, Palucha A, Borodynko N, Pospieszny H (2004) Cloning and sequencing of full-length cDNAs of RNA1 and RNA2 of a Tomato black ring virus isolate from Poland. Arch Virol.; 149: 799-807.

Kamińska M, Woś M. (1978) Some properties of isolates of Tomato black ring virus. Zeszyty Probl Post Nauk Roln.; 214: 109-17 (in Polish).

Kamińska M, Sobiło J. (1983) Choroby wirusowe forsycji (Forsythia sp.). Część I. Występowanie wirusów na forsycji. Rośliny Ozdobne.; 8: 221-8 (in Polish).

Kamińska M, Mierzwa Z. (1984) Serological characterization of TRV, TBRV and RRV isolated from forsythia. Zeszyty Probl Post Nauk Roln.; 298: 92-7 (in Polish).

Kim M-J, Kao C. (2001) Factors regulating template switch in vitro by viral RNA-dependant RNA polymerases: implications for RNA-RNA recombination. Proc Natl Acad Sci USA.; 98: $4972-7$.

Koonin EV. (1991) The phylogeny of RNA-dependent RNA polymerases of positive-strand RNA viruses. J Gen Virol.; 72: 2197-206.

Le Gall O, Candresse T, Dunez J. (1995b) Transfer of the 3' non-translated region of grapevine chrome mosaic virus RNA-1 by recombination to tomato black ring virus RNA-2 in pseudorecombinant isolates. $J$ Gen Virol.; 76: 1285-9.

Le Gall O, Lanneau M, Candresse T, Dunez J. (1995a) The nucleotide sequences of the RNA-2 of an isolate of the English serotype of tomato black ring virus: RNA recombination in the history of nepoviruses. $J$ Gen Virol.; 76: 1279-83.

Leisner SM, Neher DA. (2002) Third position codon composition suggests two classes of 
genes within the Cauliflower mosaic virus genome. J Theor Biol.; 217: 195-201.

Lin HX, Rubio L, Smythe A, Jiminez M, Falk BW. (2003) Genetic diversity and biological variation among California isolates of Cucumber mosaic virus. J Gen Virol.; 84: 249-58.

Melcher U. (2000) The 30K superfamily of viral movement proteins. J Gen Virol.; 81: 257-66.

Meyer M, Hemmer O, Mayo MA, Fritsch C. (1986) The nucleotide sequence of tomato black ring virus RNA2. J Gen Virol.; 67: $1257-71$.

Mushegian AR. (1994) The putative movement domain encoded by nepovirus RNA-2 is conserved in all sequenced nepoviruses. Arch Virol.; 135: 437-41.

Nagy PD, Bujarski JJ. (1998) Silencing homologous RNA recombination hot spots with GC-rich sequences in Brome mosaic virus. $J$ Virol.; 72: 1122-30.

Page RD. (1996) TREEVIEW: An application to display phylogenetic trees on personal computers. Comput Appl Biosci.; 12: 357-8.

Pavlicek A, Hrda S, Flegr J. (1999) FreeTree freeware program for construction of phylogenetic trees on the basis of distance data and bootstrap/jackknife analysis of the tree robustness. Application in the RAPD analysis of genus Frenkelia. Folia Biol (Praha); 45: $97-9$.

Petrzik K, Lenz O. (2002) Remarkable variability of apple mosaic virus capsid protein gene after nucleotide position 141. Arch Virol.; 147: $1275-85$.

Pospieszny H, Borodynko N. (1999) Wirus czarnej pierścieniowej plamistości pomidora (Tomato black ring nepovirus) - metody wykrywania i identyfikacji. Prog Plant Protection/Post Ochr Roślin.; 39: 327-31 (in Polish).

Pospieszny H, Jończyk M, Borodynko N. (2003) First record of Tomato black ring virus (TBRV) in the natural infection of Cucumis sativus in Poland. J Plant Prot Res.; 43: 11-8.
Roossinck MJ. (1997) Mechanism of plant virus evolution. Annu Rev Phytopathol.; 35: 191-209.

Roossinck MJ. (2002) Evolutionary history of Cucumber mosaic virus deduced by phylogenetic analyses. $J$ Virol.; 76: 3382-7.

Sambrook J, Fritsch EF, Maniatis T. (1989) Molecular Cloning. A Laboratory Manual, 2nd edn. Cold Spring Harbor Laboratory Press.

Schneider WL, Roossinck MJ. (2001) Genetic diversity in RNA virus quasispecies is controlled by host-virus interactions. $J$ Virol.; 75: $6566-71$.

Steinkellner H, Himmler G, Sagl R, Mattanovich D, Katinger H. (1992) Amino-acid sequence comparison of nepovirus coat proteins. Virus Genes.; 6: 197-202.

Szittya G, Molnar A, Silhavy D, Hornyik C, Burgyan J. (2002) Short defective interfering RNAs of Tombusviruses are not targeted but trigger post-transcriptional gene silencing against their helper virus. Plant Cell.; 14: 359-72.

Twardowicz-Jakusz, A. (1969) Diagnostic investigation of Tomato black ring virus. Inst Plant Prot Bull.; 44: 123-36.

Twardowicz-Jakusz A. (1976) Virus diseases of Umbelliferous vegetables in Poland. 8th Conference of Plant Virology, Bratislava: 445-7.

Twardowicz-Jakusz A, Kaniewski W, Dunajska L. (1977a) Z badań nad wirusami pietruszki i marchwi. I. Wirus czarnej pierścieniowej plamistości pomidora (Tomato black ring virus) na marchwi. Zeszyty Probl Post Nauk Roln.; 226: 71-87 (in Polish).

Twardowicz-Jakusz A, Kaniewski W, Dunajska-Zielińska L. (1977b) Badania diagnostyczne nad wirusami chrzanu. Zeszyty Probl Post Nauk Roln.; 195: 173-93 (in Polish).

Zaccomer B, Haenni A-L, Macaya G. (1995) The remarkable variety of plant RNA virus genomes. J Gen Virol.; 76: 231-47. 